\title{
Energy potential and economic feasibility of biogas: case study of a landfill in Minas Gerais, Brazil
}

Potencial energético e viabilidade econômica do biogás: estudo de caso de um aterro sanitário em Minas Gerais, Brasil Tatiane Leticia de Carvalho Souza ${ }^{1}$ (), André Luiz Marques Rocha ${ }^{1}$ (D), Daniel Brianezi ${ }^{1}$ (1)

\begin{abstract}
A B S T R A C T
The final disposal of solid waste in landfills may result in the production of a clean and renewable energy through the exploitation of biogas generated in these locations. This study aims to estimate the methane production in a landfill, with a total population of 237,298 inhabitants, and a total generation of waste of $83,561.78$ ton/year, in the last year of operation, located in the state of Minas Gerais and evaluate the economic feasibility of a biogas exploitation project in this place, for electrical energy generation. The methane production was estimated by the Intergovernmental Panel on Climate Change (IPCC) methodology, obtaining the maximum methane production value of $6,692,590$ $\mathrm{m}^{3}$ in the last year of operation of the landfill. For economic feasibility analysis, the tools, such as net present value, discounted payback, and internal rate of return, were used with values of $\mathrm{R} \$ 1,323,684.90$ for 8 years, 4 months, and 12 days, and $9 \%$ per annum, respectively, demonstrating that the implementation of the project for the use of biogas at the landfill was viable, with positive economic return.
\end{abstract}

Keywords: economic analysis; electrical energy; final disposal; methane gas; solid waste.

\section{R E S U M 0}

A disposição final de resíduos sólidos em aterros sanitários pode resultar na produção de energia limpa e renovável por meio do aproveitamento do biogás gerado nesses locais. O objetivo deste estudo foi estimar a produção de metano em um aterro sanitário, com população total atendida de 237.298 habitantes, e uma geração total de resíduos de $83.561,78 \mathrm{t} \mathrm{ano}^{-1}$, no último ano de operação, localizado no estado de Minas Gerais e estudar a viabilidade econômica de um projeto de aproveitamento de biogás no local do aterro, para geração de energia elétrica. Para estimar a produção de metano utilizou-se a metodologia proposta pelo Painel Intergovernamental sobre Mudanças do Clima (IPCC, 1996), obtendo-se o valor máximo de produção de metano igual a $6.692 .590 \mathrm{~m}^{3}$, no último ano de operação do aterro. Para análise de viabilidade econômica, utilizaram-se as ferramentas Valor Presente Líquido (VPL), payback descontado e Taxa Interna de Retorno (TIR), com valores encontrados de $\mathrm{R} \$ 1.323 .684,90,8$ anos, 4 meses e 12 dias, e $9 \%$ a.a., respectivamente, demonstrando que a implantação do projeto de aproveitamento de biogás no aterro foi viável, apresentando retorno econômico positivo.

Palavras-chave: análise econômica; energia elétrica; disposição final; gás metano; resíduos sólidos.

${ }^{1}$ Centro Federal de Educação Tecnológica de Minas Gerais - Belo Horizonte (MG), Brazil.

Correspondence address: Tatiane Leticia de Carvalho Souza - Av. Amazonas, 5253 - Nova Suíça - CEP: 30421-169 - Belo Horizonte (MG), Brazil E-mail: tatianecsouza14@gmail.com

Conflicts of interest: The authors declare that there are no conflicts of interest.

Funding: none.

Received on: 09/30/2020. Accepted on: 07/13/2021

https://doi.org/10.5327/Z21769478935 


\section{Introduction}

The increase in the urban population combined with changes in consumption habits caused an increase in the production of urban solid waste (ICLEI, 2009). These residues, when disposed inappropriately, result in public health and environmental problems, such as the proliferation of vectors and diseases and pollution of soil, water, and air (Figueiredo, 2011). Most of the solid waste collected in Brazil is destined for landfills. Between 2018 and 2019, about 59.5\% of the total solid waste collected went to landfills (ABRELPE, 2019), which are a form of environmentally appropriate final disposal provided by the National Solid Waste Policy (Brasil, 2010). However, there are some environmental problems related to this form of final disposal, among them is the emission of gases.

According to the Ministry of the Environment (Brasil, 2019), the landfill can be considered a biological reactor in which one of the main products generated are the gases that have mainly methane and carbon dioxide in their composition, which are greenhouse gases, with methane having a potential of causing global warming 21 times greater than carbon dioxide (IPCC, 2013). Therefore, it is clear that biogas generated in landfills can be characterized as a global problem, thus highlighting the importance of using it as an alternative to avoid the emission of this gas and, in return, generate a source of clean energy, because it has a high energy potential and is a renewable, economically viable, and environmentally correct source of energy (Bianek et al., 2018).

The Brazilian energy matrix places the country at an advantage in the generation of renewable energy, as it has one of the cleanest matrices in the world (Freitas and Makiya, 2012). Of the electricity produced in the country, $81.4 \%$ comes from renewable sources, while $22.8 \%$ of the energy comes from renewable sources and the rest from nonrenewable sources globally. However, most of the renewable energy produced in Brazil comes from hydroelectric power stations (EPE, 2018b). As the Brazilian energy matrix is based on hydropower, the generation of new forms of electrical energy, such as that coming from biogas, is not encouraged with the same intensity (Arcadis, 2010).

According to Durão (2017), Brazil has the potential for generating electrical energy through the use of biogas in landfills, but this energy potential is still very less explored, and the generation corresponds only to $1,22 \%$ of the total energy matrix in Brazil (ANEEL, 2020).

Some examples of thermal power stations using biogas in landfills in Brazil are: the Biogas Thermal Power Station at the Solid Waste Treatment Center on BR-040, in Belo Horizonte (MG); the Thermal Power Station at the landfill in Uberlândia, Uberlândia (MG); the ValorGás Thermal Power Station, Juiz de Fora (MG); the Bandeirantes Thermal Power Station, São Paulo (SP); the Biogas Thermal Power Station at the Sítio São João Landfill, São Paulo (SP); the Thermal Power Station of Guatapará, Guatapará (SP); the Termoverde Salvador Power Station, Salvador (BA); the Itajaí Biogás e Energia S.A. Thermal Power Station, Canhanduba (SC); and the Recreio Biothermal Power
Station, Minas do Leão (RS). These power stations were implemented between 2004 and 2015 in Brazil and have a total installed potential of 86.3 MW for generating electrical energy, most of which are present in landfills in the Southeast region of the country (Nascimento et al., 2019). In addition, it is worth mentioning Termoverde Caieiras, the largest thermal power plant powered by landfill biogas in Brazil, with an installed power of 29.5 MW (ANEEL, 2020).

Thus, it is clear that there are few biogas projects in operation in the country, although there is potential for its use, and this is explained by the existence of some difficulties mainly related to the economic feasibility and operational problems of the system (Arcadis, 2010).

Therefore, the technical and economic feasibility studies for the implementation of this energy source are important to promote its expansion and the exploitation of this potential available in Brazil, considering the importance of the energy use of biogas in landfills as an alternative for the reduction of greenhouse gas emissions and for the diversification of the Brazilian energy matrix.

Thus, this study aimed to estimate the energy potential of biogas and the economic feasibility of its use for the production of electrical energy in a landfill that serves three municipalities located in the Metropolitan Mesoregion of Belo Horizonte, in the state of Minas Gerais.

\section{Literature review}

\section{Quantification of landfill biogas}

The quantification of biogas generated in landfills can be done through mathematical models that use data about the landfill, such as precipitation, mass of waste deposited, characteristics of the site and waste, to conduct the theoretical estimate of methane produced (Barros, 2012). Currently, the most commonly used methods are based on first-order decay equations. These models consider that the age of the waste has an influence on the production of biogas and that there is a decrease in production over the years, from a certain amount of waste disposed in the landfill (ABRELPE, 2013).

Among the models that use first-order kinetics, we can mention the methodology proposed by the Intergovernmental Panel on Climate Change (IPCC, 1996), a methodology that is simple to apply to calculate methane emissions. In this method, the amount of degradable organic carbon (DOC) present in solid waste is estimated for specific regions, requiring statistical data on the population and urban solid waste (Vieira et al., 2015).

\section{Energy exploitation of biogas in landfills}

According to the Ministry of the Environment (Brasil, 2019), the energy exploitation of biogas aims to transform it into other forms of energy such as electric, steam, fuel for boilers or stoves, vehicle fuel, or for supplying gas pipelines. The energy potential of biogas is due to its high methane content, which makes it suitable for several applications in the field of energy generation (ICLEI, 2009). 
In a landfill, this process occurs through the conversion of chemical energy present in organic matter molecules into mechanical energy that activates a generator, thus producing electrical energy. Methane is the constituent of biogas used to fuel engines and generators for the production of electrical energy in landfills, reducing the negative impacts generated by its emission through complete combustion for energy purposes (Landim and Azevedo, 2008).

According to ICLEI (2009), the biogas extraction system has vertical and horizontal drains, blowers, filters responsible for removing particulate material, and condensate separating tanks; and for the generation of electrical energy, generator sets are used, such as microturbines and internal combustion engines, the latter being the most used in projects aimed at generating electrical energy from landfill biogas, due to the compatibility of power with the economic feasibility of the project (Barros, 2012), presenting higher electrical efficiency and lower cost when compared with other technologies (ICLEI, 2009).

According to USEPA (2021), biogas is extracted from landfills using vertical wells, drilled into the residual mass, and connected to horizontal wells and a blower/flare system. The gas is then directed, through this system, to a central point where it can be treated according to its final use, and can be burned or used in energy generation projects.

\section{Economic feasibility of using biogas as electrical energy}

The implementation of electrical energy generation systems in landfills requires the execution of technical and economic feasibility studies, in order to verify the potential of biogas generation in the landfill, due to the amount of organic matter present in the waste, and to evaluate the electrical energy generation costs (Van Elk, 2007).

There are some factors that indicate the possibility of a landfill being economically viable or not for the installation of biogas energy exploitation projects. Among them, we can mention the population served of at least 200,000 inhabitants (Arcadis, 2010; Barros et al., 2014), receiving a minimum daily amount of waste of 200 tons and 500,000 total tons in its life span (Johannessen, 1999).

According to Costa (2016), the implementation of inter-municipal consortia makes the implementation of biogas energy exploitation projects viable, since municipalities that meet small demands of inhabitants generate a small amount of energy from biogas, which can make the project hardly viable. The consortia enable the installation of projects of capture, burn, and energy exploitation of biogas for the production of electrical energy, because the greater the volume of organic waste deposited in a single landfill, the greater the generation of methane gas (Arcadis, 2010). Therefore, the formation of consortia is an initiative that should be encouraged and has proven to be efficient, especially for municipalities with populations of less than 100,000 inhabitants (Arcadis, 2010).

\section{Methodology}

\section{Description of the study site}

The landfill where the study of biogas production and the analysis of the economic feasibility of its use for the production of electrical energy was conducted, is located in the state of Minas Gerais and serves three small- and medium-sized municipalities that dispose their waste to the site through the formation of a consortium. For reasons of confidentiality, the name of the landfill, as well as the municipalities served by it, were omitted. We chose to name them as municipalities A, B, and C. However, the data used are true. Table 1 presents socioeconomic data for municipalities $\mathrm{A}, \mathrm{B}$, and $\mathrm{C}$.

The landfill started its operation in August 2014, with a population served, till this year, equals 200,045 inhabitants. The site has a disposal area equal to 14.8 ha and has an expected life span of 15 years.

Figure 1 summarizes the methodological steps used to conduct the calculations in this study.

Step 1: Estimation of the population and generation of solid waste in the municipalities served by the landfill

We used the arithmetic growth methodology to estimate the population projection for all municipalities served by the landfill. This model assumes population growth at a constant rate equal to the growth rate of the last 2 years for which we have data, and is represented by Equations 1 and 2 (Qasim, 1985).

$P_{(t)}=P_{0}+K_{a}\left(t-t_{0}\right)$

$\mathrm{K}_{\mathrm{a}}=\frac{\mathrm{P}_{1}-\mathrm{P}_{0}}{\mathrm{t}_{1}-\mathrm{t}_{0}}$

Where:

$\mathrm{P}_{(\mathrm{t})}=$ the estimated population in year $\mathrm{t}$ (inhab.);

$\mathrm{K}_{\mathrm{a}}=$ the coefficient;

$t_{0}$ and $t_{1}=$ years of the last demographic censuses;

$\mathrm{P}_{1}$ and $\mathrm{P}_{0}=$ populations in years $\mathrm{t}_{1}$ and $\mathrm{t}_{0}$ (inhab.).

We used the population data from the last two censuses conducted by the Brazilian Institute of Geography and Statistics, corresponding to the years 2000 (IBGE, 2000) and 2010 (IBGE, 2010), referring to the urban population.

Table 1 - Socioeconomic data for municipalities A, B, and C.

\begin{tabular}{|l|c|c|c|c|}
\hline & $\begin{array}{c}\text { Population } \\
\text { (year 2000) }\end{array}$ & $\begin{array}{c}\text { Population } \\
\text { (year 2010) }\end{array}$ & $\begin{array}{c}\text { GDP per } \\
\text { capita }\end{array}$ & HDI \\
\hline $\mathrm{A}$ & 39,458 & 47,236 & $\mathrm{R} \$ 31,529.18$ & 0.753 \\
\hline $\mathrm{B}$ & 99,515 & 111,266 & $\mathrm{R} \$ 16,555.58$ & 0.761 \\
\hline $\mathrm{C}$ & 26,303 & 31,609 & $\mathrm{R} \$ 104,169.26$ & 0.764 \\
\hline
\end{tabular}

Source: IBGE $(2000,2010,2018)$ and PNUD (2010). 
Once the populations for the municipalities were calculated up to the year the landfill was closed, it was possible to calculate the generation of solid waste disposed each year. For this, we used data on the per capita generation of urban solid waste collected in the state of Minas Gerais, a value equal to $0.831 \mathrm{~kg} /$ inhabitant.d (ABRELPE, 2014).

We considered, as proposed by Barros (2012), an increase of $1 \%$ over the per capita rate per year, a percentage that considers the trend of increased consumption, and consequently, the generation of solid waste by the population over the years.

Thus, multiplying the total population, referring to the sum of the three municipalities, by the per capita production for that year and by the number of days in the year, we obtained the annual production of solid waste disposed in the landfill.

Step 2: Estimation of the methane gas production in the landfill

We used the method suggested by the IPCC (1996) to estimate the potential for methane gas generation, which is a model that theoretically projects the volume of methane to be generated in a given time. We calculated the methane emission in the landfill from Equation 3.

$\mathrm{Q}_{\mathrm{x}}=\mathrm{K} \cdot \mathrm{R}_{\mathrm{X}} \cdot \mathrm{L}_{0 .} \mathrm{e}^{-\mathrm{k}(\mathrm{X}-\mathrm{T})}$

Where:

$\mathrm{Q}_{\mathrm{x}}=$ the methane emission ( $\mathrm{m}^{3} /$ year);

$\mathrm{K}=$ the decay constant;

$\mathrm{R}_{\mathrm{x}}=\mathrm{R}_{(\mathrm{t})}=$ the waste stream of the year $(\mathrm{t})$;

$\mathrm{L}_{0}=$ the waste methane generation potential $\left(\mathrm{m}^{3} /\right.$ ton $)$;

$\mathrm{X}=$ the current year;

$\mathrm{T}=$ the year of disposal of waste in the landfill (start of operation).

The IPCC equation, mentioned above, is applied by the Environmental Company of the State of São Paulo (CETESB, 2006) in the Biogás, generation and energy use-landfills ${ }^{\circledR}$ software and was used to obtain the methane generation curve.

It is necessary to know the methane gas generation potential $\left(\mathrm{L}_{0}\right)$ to estimate the methane emission. This parameter depends on the composition of the waste, especially its organic portion, and its value is estimated from the carbon content of the waste and its biodegradable fraction and a factor for the stoichiometric conversion of $\mathrm{CO}_{2}$ into $\mathrm{CH}_{4}$
(IPCC, 2006). We made the calculation using the equation proposed by IPCC (2006), represented by Equation 4.

$\mathrm{L}_{0}=$ MCF. DOC. DOC $\mathrm{f} \cdot \mathrm{F} \cdot \frac{16}{12}$

Where:

$\mathrm{L}_{0}=$ the waste methane generation potential $\left(\mathrm{m}^{3} /\right.$ ton);

$\mathrm{MCF}=$ the methane correction factor;

$\mathrm{DOC}=$ the degradable organic carbon;

$\mathrm{DOC}_{\mathrm{f}}=$ the dissociated DOC fraction;

$\mathrm{F}=$ the fraction of methane present in biogas in volume;

$(16 / 12)=$ the carbon to methane conversion factor.

The variable amount of DOC becomes important to know in order make the calculations regarding the methane generation potential. It represents the organic carbon from waste that is available for biochemical decomposition. Its calculation can be made from Equation 5.

$\mathrm{DOC}=(0.40 . \mathrm{A})+(0.17 . \mathrm{B})+(0.15 . \mathrm{C})+(0.30 . \mathrm{D})$

Where:

$\mathrm{A}=$ the fraction of paper, cardboard and textile of waste;

$\mathrm{B}=$ the fraction of parks' and gardens' debris of waste;

$\mathrm{C}=$ the fraction of food waste;

$\mathrm{D}=$ the fraction of wood waste.

The IPCC (1996) suggests, in the case where there is no data referring to the gravimetric composition of the waste from the studied landfill, the DOC value equal to 0.12 to be used for Brazil.

According to Bingemer and Crutzen (1987), the dissociated DOC fraction can be obtained by Equation 6. DOCf corresponds to the fraction of DOC that can decompose in an anaerobic way.

$\mathrm{DOC}_{\mathrm{f}}=0.014 . \mathrm{T}+0.28$

Where:

$\mathrm{DOC}_{\mathrm{f}}=$ the dissociated DOC fraction;

$\mathrm{T}=$ the temperature in the anaerobic zone $\left({ }^{\circ} \mathrm{C}\right)$.
Step 1

\begin{tabular}{|l|}
\hline $\begin{array}{c}\text { Population } \\
\text { Estimation and } \\
\text { Solid Waste } \\
\text { Production }\end{array}$ \\
$\begin{array}{c}\text { Methane } \\
\text { Production } \\
\text { Estimation }\end{array}$ \\
\hline
\end{tabular}

Step 3

Calculation of
Avaliable Power
and Energy

Step 4

Evaluation of Economic Feasibility

Figure 1 - Flowchart of the calculation methodology used.

Source: Own elaboration (2021). 
The value for the MCF, necessary for the calculation of $\mathrm{L}_{0}$, is related to the conditions of solid waste disposal, the operation control, and the site management. The value of this parameter was adopted according to the default values proposed by IPCC (2006), which are presented in Table 2.

In addition to parameter $\mathrm{L}_{0}$, the decay constant $\mathrm{k}$ is also important. This constant is related to the time required for a portion of DOC present in the waste to decay to half of its initial mass. The constant $\mathrm{k}$ was adopted as proposed by IPCC (2006).

Thus, from $\mathrm{L}_{0}$, the decay constant $\mathrm{k}$ and the waste stream in the year, we used Equation 3 to estimate the amount of methane emitted per year in the landfill.

Step 3: Calculation of the power and energy available in the landfill

The calculation of available power was made from Equation 7, modified from CETESB (2006) by Barros (2012).

$P x=Q_{x} \cdot E \cdot E_{c} \cdot P_{\mathrm{cCH}_{4}} \cdot \frac{1}{31,536,000} \cdot \frac{1}{1,000}$

Where:

$\mathrm{P}_{\mathrm{x}}=$ the available power each year $(\mathrm{kW})$;

$\mathrm{Q}_{\mathrm{x}}=$ the methane flow each year $\left(\mathrm{m}^{3} /\right.$ year $)$;

$\mathrm{P}_{\mathrm{cCH} 4}=$ the methane calorific value $\left(\mathrm{J} / \mathrm{m}^{3}\right)$;

$\mathrm{E}_{\mathrm{c}}=$ the biogas collection efficiency (\%);

$\mathrm{E}=$ the engine efficiency (\%);

$31,536,000=$ the number of seconds in a year;

$1 / 1,000=$ for unit transformation from $\mathrm{J} / \mathrm{s}$ to $\mathrm{kW}$.

Equation 8 was used to calculate the available energy (CETESB, 2006).

$E=P_{x} \cdot t$

Where:

$\mathrm{E}=$ the available energy $(\mathrm{kWh} / \mathrm{year})$;

$\mathrm{P}_{\mathrm{x}}=$ the available power $(\mathrm{kW})$;

$\mathrm{t}=$ the engine operating time $(\mathrm{h} /$ year $)$.

Step 4: Evaluating the economic feasibility of the project

We conducted an analysis based on the composition of the cash flow, which includes the project costs, considering the initial investment and

Table 2 - Classification of solid waste disposal sites and MCF.

\begin{tabular}{|c|c|}
\hline Type & MCF \\
\hline Managed-anaerobic & 1 \\
\hline Managed-semi-aerobic & 0.5 \\
\hline Unmanaged-deep $(>5$ m of waste) and/or high water table & 0.8 \\
\hline Unmanaged_shallow (<5 m of waste) & 0.4 \\
\hline Uncategorized & 0.6 \\
\hline
\end{tabular}

Source: translated from IPCC (2006). expenses with operation and maintenance and the revenue obtained from the sale of electrical energy, in order to evaluate the economic feasibility of the project. We considered the investment costs with the collection system, treatment and purification system, compression, biogas burning, and electrical energy generation, being necessary to know the number of drains and the length of the collection pipe, calculated according to CETESB (2006).

From the composition of the cash flow, we used the net present value (NPV), internal rate of return (IRR), and discounted payback tools to conduct the economic evaluation of the project. These methods, especially IRR and NPV, are the best known and mostly used in investment analysis (Samanez, 2002).

NPV is a technique that explicitly considers the time value of money and was calculated according to Equation 9, modified from Gitman (2010). This method is used with the objective of verifying whether the project will present a greater value to the investor than the cost spent by him (Samanez, 2002).

$\mathrm{NPV}=\sum_{\mathrm{t}=1}^{\mathrm{n}} \frac{\mathrm{CF}_{\mathrm{t}}}{(1+\mathrm{MARR})^{\mathrm{t}}}-\mathrm{CF}$

Where:

$\mathrm{NPV}=$ the net present value;

$\mathrm{n}=$ the discount time of the last cash flow;

$\mathrm{t}=$ the discount time for each cash entry;

$\mathrm{MARR}=$ the minimum attractive rate of return;

$\mathrm{CF}_{\mathrm{t}}=$ the present value of cash flow;

$\mathrm{CF}_{0}=$ the initial investment.

The results obtained from the calculation of the NPV were analyzed as follows: if NPV $>0$, the project must be accepted; and if NPV $<0$, the project must be rejected (Gitman, 2010).

In addition, the IRR was calculated, which is a rate that represents the annual return that the company will obtain if it decides to invest in the project (Gitman, 2010). The IRR is calculated by equating the NPV (Equation 9) to 0.

We used the multi-index methodology, which consists of a comparison between the IRR and the MARR (Motta and Calôba, 2002). The MARR is an interest rate that represents the minimum that an investor intends to earn when making an investment and, therefore, is unique for each investor and there is no formula to calculate it, as it can vary over time (Casarotto Filho and Kopittke, 1994). The comparison between the two rates can be made according to Table 3 .

Table 3 - Comparison between IRR and MARR.

\begin{tabular}{|c|c|}
\hline IRR $>$ MARR & Investment is viable \\
\hline IRR $<$ MARR & Investment is not viable \\
\hline IRR $=$ MARR & It is indifferent to invest \\
\hline
\end{tabular}

Source: Motta and Calôba (2002). 
We also calculated the discounted payback, with the objective of verifying the time of return on the investment, being one more way to measure the economic feasibility of the project. This method is based on the time required for the present value of the company's forecast cash flows to equal the value of the initial investment made (Samanez, 2002). We calculated the discounted payback from the present value of the discounted cash flow each year, calculating the balance until it became positive.

\section{Results and Discussion}

Step 1: Population estimate and solid waste generation in the municipalities served by the landfill

Using population data from the 2000 and 2010 censuses and the arithmetic growth methodology, Equations 1 and 2, presented in step 1 of the methodology, was possible to calculate the projection for all municipalities served by the landfill for the years 2014-2029. Figure 2 shows the projection for the total population served by the site, equal to the annual sum of the three municipalities, for each year of the landfill's useful life.

Some authors claim in their studies that the minimum population for a biogas project to be economically viable must be equal to 200,000 inhabitants (Arcadis, 2010; Barros et al., 2014), which is met by the present study, demonstrating the tendency to obtain positive results regarding the feasibility of implementing this technology in the studied landfill.

We estimated the annual projection for solid waste disposal, and the total mass for each year, the daily disposal in each year, and the annual accumulation of solid waste are presented in Table 4.

The amount of waste deposited in the landfill increases over the years, with the increase in population, demonstrating the proportionality relationship between these variables. Thus, the consortia are solutions both for the treatment and final disposal of waste and for the gain of scale, as they allow the service to be provided to a greater number of municipalities. Therefore, the consortia collaborate with a better optimization of resources and minimization of environmental impacts.

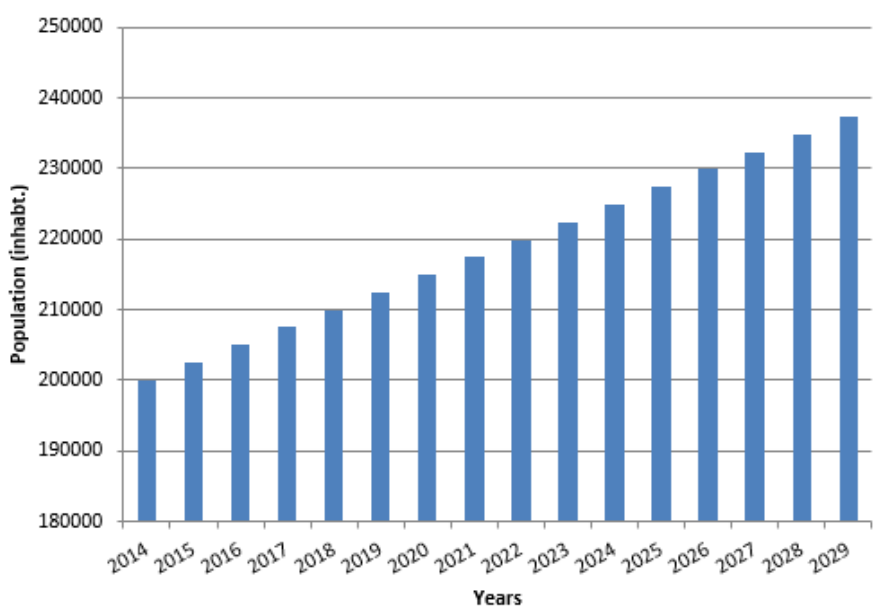

Figure 2 - Population projection for all municipalities served by the landfill. Source: Own elaboration (2021).
As for the population, there is a minimum amount of waste that the landfill must receive so that it is interesting to implement biogas energy exploitation projects with a positive economic return. According to data provided in studies by Johannessen (1999), this amount equals 200 ton/day. Analyzing the amount of waste received each year, separately, only from the year 2023, the landfill starts receiving the minimum amount of solid waste per day. On the other hand, the landfill will receive the amount of waste over 500,000 tons throughout its useful life, a value also established by the same author.

The daily average of solid waste disposal in the landfill, considering the total value of waste received during its entire useful life, is equal to 196.47 ton/day, and the total accumulation of waste over the 15 years of the landfill's operation is equal to $1,102,014.6$ tons.

We considered that all waste collected in the three municipalities is disposed in the landfill, not considering previous stages of treatment. This is due to the fact that the formation of the consortium took place, precisely, to allow the municipalities to have an environmentally adequate final destination, and, consequently, they did not have initiatives such as recycling either. However, it is noteworthy that over the years, other treatments can be adopted by the municipalities, which may lead to changes in the total amount of solid waste disposed at the site and, consequently, in the generation of methane gas.

Step 2: Estimation of the production of methane gas in the landfill

We made theoretical estimate of methane gas generation in the landfill. Therefore, it was necessary to know the potential for $\mathrm{L}_{0}$ meth-

Table 4 - Total amount of waste disposed in the landfill per year, per day, and annual accumulated.

\begin{tabular}{|l|c|c|c|}
\hline Year & $\begin{array}{c}\text { Daily waste } \\
\text { amount (ton/day) }\end{array}$ & $\begin{array}{c}\text { Annual waste } \\
\text { amount (ton/year) }\end{array}$ & $\begin{array}{c}\text { Accumulated } \\
\text { (ton/year) }\end{array}$ \\
\hline 2014 & 166.24 & $15,293.84$ & $15,293.84$ \\
\hline 2015 & 169.98 & $62,044.23$ & $77,338.07$ \\
\hline 2016 & 173.79 & $63,433.10$ & $140,771.17$ \\
\hline 2017 & 177.65 & $64,843.54$ & $205,614.71$ \\
\hline 2018 & 181.58 & $66,275.84$ & $271,890.55$ \\
\hline 2019 & 185.56 & $67,730.31$ & $339,620.85$ \\
\hline 2020 & 189.61 & $69,207.24$ & $408,828.09$ \\
\hline 2021 & 193.72 & $70,706.93$ & $479,535.02$ \\
\hline 2022 & 197.89 & $72,229.70$ & $551,764.71$ \\
\hline 2023 & 202.13 & $73,775.85$ & $625,540.56$ \\
\hline 2024 & 206.43 & $75,345.70$ & $700,886.26$ \\
\hline 2025 & 210.79 & $76,939.57$ & $777,825.82$ \\
\hline 2026 & 215.23 & $78,557.78$ & $856,383.61$ \\
\hline 2027 & 219.73 & $80,200.67$ & $936,584.27$ \\
\hline 2028 & 224.3 & $81,868.55$ & $1,018,452.82$ \\
\hline 2029 & 228.94 & $83,561.78$ & $1,102,014.60$ \\
\hline
\end{tabular}

Source: Own elaboration (2021). 
ane generation and, consequently, the percentage of DOC and the fraction of dissociated DOC.

As the data referring to the gravimetric composition of the landfill were not known, we adopted the DOC value equal to 0.12 (IPCC, 1996).

Considering Equation 6, and assuming an anaerobic zone temperature of $35^{\circ} \mathrm{C}$ (Bingemer and Crutzen, 1987), we obtained the $\mathrm{DOC}_{\mathrm{f}}$ value equals 0.77 .

Finally, we calculated the value of $\mathrm{L}_{0}$ from Equation 4, considering the value of the MCF equal to 1 , for anaerobic managed sites, proposed by the IPCC (2006), which is the commonly assigned value to landfills. The fraction of methane present in the biogas (F) was considered equal to $50 \%$, also proposed by the IPCC (2006).

To obtain $\mathrm{L}_{0}$ in the unit in which it is requested, it was necessary to divide the value found by the specific mass of methane, equal to $0.0007168 \mathrm{ton} / \mathrm{m}^{3}$ (ICLEI, 2009).

Then, we established the value of the decay constant $(\mathrm{k})$. Considering that the average annual precipitation for the municipality where the landfill is located, with historical data of 30 years, is $1,436 \mathrm{~mm} /$ year (Climatempo, 2019) and adopting the values proposed by IPCC (2006), for wet waste, for places with precipitation greater than 1,000 $\mathrm{mm}$ /year, tropical climate, with average temperatures greater than $20^{\circ} \mathrm{C}$ and the type of municipal solid waste as a whole, the value of $\mathrm{k}$ used for calculations was equal to 0.170 per year.

Table 5 presents the input data of the Biogás, generation and energy use-landfills ${ }^{\circledR}$ software (CETESB, 2006).

Applying all the data obtained prior to Equation 3 through the Biogas, generation, and energy use-landfills ${ }^{\circledR}$ software (CETESB, 2006), we obtained the methane flow values presented in Figure 3.

In Figure 3, we observed that the production of methane increases over time, as solid waste is disposed in landfill and decays after its closure, reaching its maximum value in the year of closure of receiving waste with value of $6,692,590 \mathrm{~m}^{3}$ of methane generated. Since then, there is a decrease in methane generation, which is mainly due to the cessation of waste accumulation at the site.

Considering the minimum amount of daily waste that must be disposed in the landfill in order to obtain a viable project for the ex-

Table 5 - Input parameters of biogas, generation, and energy uselandfills software.

\begin{tabular}{|c|c|}
\hline Parameter & Input \\
\hline Opening year of the landfill & 2014 \\
\hline Closure year of the landfill & 2029 \\
\hline $\mathrm{k}$ (per year) & 0.170 \\
\hline $\mathrm{L}_{0}\left(\mathrm{~m}^{3} /\right.$ ton $)$ & 85.94 \\
\hline Concentration of $\mathrm{CH}_{4}$ in biogas $(\%)$ & 50 \\
\hline Mass of waste disposed per year (ton/year) & Table 3 \\
\hline
\end{tabular}

Source: Own elaboration (2021). ploitation of biogas equal to 200 tons (Johannessen, 1999), adopting the same characteristics of the studied landfill, with values of $\mathrm{L}_{0}$ equal to $85.94 \mathrm{~m}^{3} /$ ton and $\mathrm{k}=0.170$ per year and applying Equation 3 , we can say that the minimum methane flow for the project to exploit biogas for commercialization to be economically viable is equal to $1,066.515 \mathrm{~m}^{3} /$ year. As shown in Figure 3, it is noteworthy that this value is met from 2015 to 2039 and, therefore, we believe that the implementation of a project within this time interval can bring positive economic return for the landfill.

It is noteworthy that not all biogas produced in the landfill will be captured and used. When landfills have well-designed, constructed, and operated collection systems, the collection of biogas can be $\geq 75 \%$ (World Bank, 2004; CETESB, 2006). However, considering that there may, for example, be possible operational problems and losses with fugitive emissions and oxidation by the cover layer (Silva et al., 2013), and to bring greater financial reliability to the project, we adopted in this study a value of $65 \%$ of efficiency in capturing biogas.

Step 3: Calculation of the power and energy available in the landfill

We used Equation 7 to estimate the available power, adopting the values of $65 \%$ of biogas collection efficiency, methane calorific value equal to $35.53 \times 10^{6} \mathrm{~J} / \mathrm{m}^{3}$ (CETESB, 2006), efficiency of internal combustion engine equal to 33\% (World Bank, 2004), and methane flow each year according to Figure 3.

Then, we calculated the available energy from Equation 8, using the data obtained for the powers each year and considering that the operation will take place $24 \mathrm{~h}$ /day for 365 days. Figure 4 demonstrates the behavior of the power and energy curve over the years of the estimate.

We observed that both power and available energy increased over the years of landfill's operation, reaching maximum values of $1,617.37$ $\mathrm{kW}$ and $14,168,185.14 \mathrm{kWh}$, respectively, in the same year in which the peak of biogas generation occurs. The average power and energy found, according to the estimate, were equal to $796.89 \mathrm{~kW}$ and $6,980,713.18$ kWh, respectively.

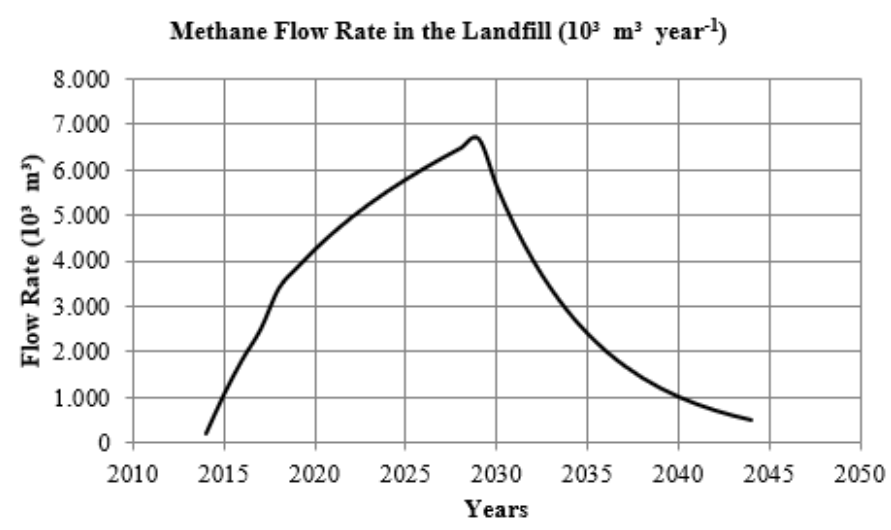

Figure 3 - Methane generation curve in the landfill. Source: Own elaboration (2021). 
Considering that all the power produced annually in the landfill is used to generate electrical energy and knowing that the mean consumption per residence in Brazil is approximately $123.6 \mathrm{kWh} / \mathrm{month}$ (EPE, 2018a), we can say that the energy generated by the studied landfill, in the year with the highest peak, would be able to supply approximately 9,550 residences. With this, we perceived the existing potential in the place for the generation of electrical energy through the methane produced from the solid waste disposed in the landfill.

As observed in Figure 4, the power produced varies over the years in the landfill, but not all the power produced will be used, as an initial investment must be made in which the power station is sized for a constant biogas flow, or with a known range. So, it becomes necessary to choose a power for the implementation of the station, as well as the number of generator sets. The choice of the power to be installed, which generates a maximum benefit, is still not much discussed in the current literature when referring to energy exploitation of biogas and, in most cases, it is done arbitrarily, without a defined methodology (Santos, 2015).

In the present work, we proposed the use of a single generator set with fixed power of $1,200 \mathrm{~kW}$, capable of operating for 9 years, meeting the power demand from the year 2022 to 2030. The choice of the proposed power can be justified by the existence of motor-generator groups in the market powered by biogas with power compatible with this generation, and the higher percentage of use of the methane generated when compared with other powers for the same period, equal to $71.94 \%$, with the best cost-benefit ratio.

The acquisition of a new generator set for the years after 2030, to meet the power of the period, was not considered, as, in line with what is described by ABRELPE (2013), as the methane flow tends to decrease after 2029, and, consequently, present a decreasing potential for using the biogas generated, acquiring a new generator set would greatly increase the costs for an exploitation that would be declining and no longer profitable.

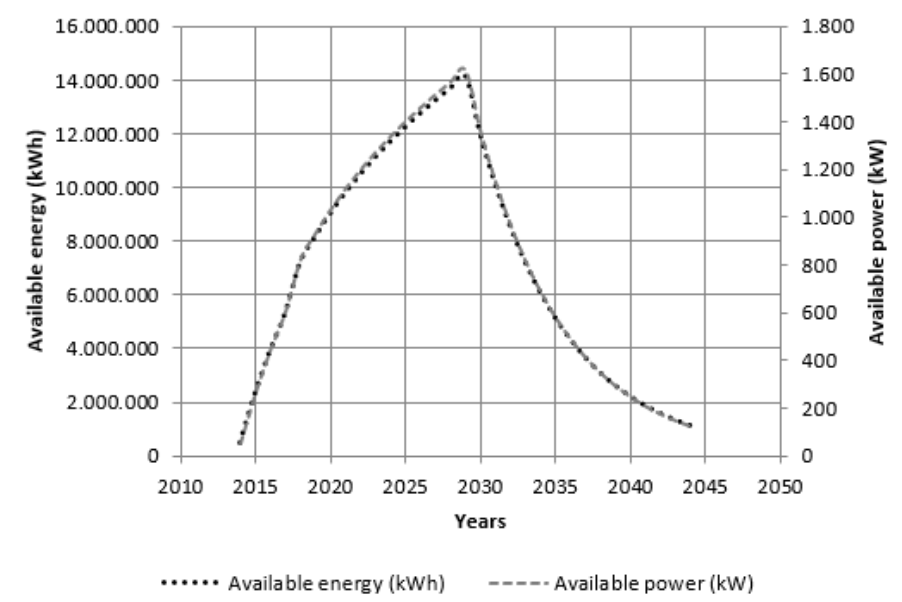

Figure 4 - Power and energy available in the landfill.

Source: Own elaboration (2021).
The exploitation of biogas generated using 1.2 MW power for the period from 2022 to 2030 comprises $71.94 \%$ of the total methane produced. The energy equivalent to this power, calculated through Equation 8 , is equal to $10,512 \mathrm{MWh}$ per project year and the corresponding flow, calculated from Equation 7, is equal to $368.45 \mathrm{~m}^{3} / \mathrm{h}$.

\section{Step 4: Evaluating the economic feasibility of the project}

Applying the methodology proposed by the manual presented by CETESB (2006), we obtained the values for the sizing and exploitation of biogas system components, as shown in Table 6 .

The project's investment cost presented a final value equal to $\mathrm{R} \$ 7,432,692.97$. We adopted the values referring to the operation and maintenance costs of each of the systems in accordance with what is proposed by ICLEI (2009), which uses the value of $3 \%$ and $2 \%$ of the total investment value for expenses with the maintenance of the wells and expenses with the maintenance of the flare and extraction system, respectively. In addition, we adopted a value of $5 \%$ of the initial investment for maintenance expenses for the electrical energy generator engine (Santos, 2015). Therefore, operating and maintenance costs, considered fixed for all years, were $\mathrm{R} \$ 743,269.30$. Operator, management, and administration salary costs were not considered.

Revenues accounted from the sale of biogas, for the calculated value of 10,512 MWh per year, considering the energy sale tariff equal to R\$187.9 per MWh, value obtained in the A- 6 energy auction of the Brazilian Electricity Regulatory Agency for new projects of energy source from thermal to biomass (ANEEL, 2016), presented an annual value equal to $\mathrm{R} \$ 1,975,204.80$, which was considered fixed for all years of the project. It is important to highlight that the tariff with the sale of electrical energy was considered constant for all years of the project, but it varies according to the auctions conducted, and in this work, the value of the most recent auction developed by ANEEL in the year of 2019 is considered.

Table 7 presents the results obtained in the economic feasibility analysis, which will be described.

In order to conduct the investment analysis of the project, we compared the IRR to the Selic rate (Special Clearance and Escrow System), which is the most conservative opportunity cost in the Brazilian economy, defined by Bank of Brazil, representing the interest rate of the expected return of a low-risk investment fund in Brazil and, according to ABRELPE (2013), it is applicable for investments in biogas energy exploitation.

The value of the most recent Selic rate, on the date of this study, referring to November 2019, is equal to 5\% p.a. (BACEN, 2019b). This rate was also used to calculate the present value of the cash flow, to obtain the discounted payback and to apply Equation 9, which refers to the NPV. For the calculating purposes of this study, the Selic rate was considered fixed, but it varies frequently and this fluctuation can directly influence the economic feasibility of the project, since very high values for this rate can make investment projects unfeasible. 
We calculated the cash flow, for the 9 years of the project, considering the revenues subtracted from the costs listed above, obtaining a value for the NPV, from the application of Equation 9, equal to $\mathrm{R} \$ 1,323,684.90$. Therefore, as NPV $>0$, the project must be accepted, that is, it is viable to invest in it.

The IRR presented a value equal to $9 \%$ p.a., therefore, considering the MARR equal to the Selic rate, $5 \%$ p.a., and applying the multi-index methodology, we can consider that the investment is viable, since the following relationship is true: IRR > MARR.

We also calculated the discounted payback with the objective of knowing the time of return on the investment made. For this, it was necessary to calculate the discounted cash flow, bringing it to the present value, thus obtaining the balance each year until the value becomes positive. The time required for the investment in the project to be paid is equal to 8 years, 4 months, and 12 days, which corresponds to the year of 2029. Figure 5 shows the year in which the balance becomes positive.

It is important to emphasize that a simplified analysis of investment, operation, and maintenance costs was conducted, considering only the main components of the biogas energy exploitation system for the purpose of producing electrical energy. In more in-depth studies, it should be considered other factors such as those cited by USEPA (2008), which include in the initial investment costs with en- gineering, legal, commercial, accounting, and other professional services, transport, and delivery of equipment and interconnection with the electrical network; and annual costs, which include, in addition

Table 7 - Results obtained for IRR, NPV, and discounted payback.

\begin{tabular}{|c|c|}
\hline Parameter & Result obtained \\
\hline IRR & $9 \%$ p.a. > MARR $(=5 \%$ p.a. $)$ \\
\hline NPV & R\$ $1,323,684.90$ \\
\hline Discounted payback & 8 years, 4 months and 12 days \\
\hline
\end{tabular}

Source: Own elaboration (2021).

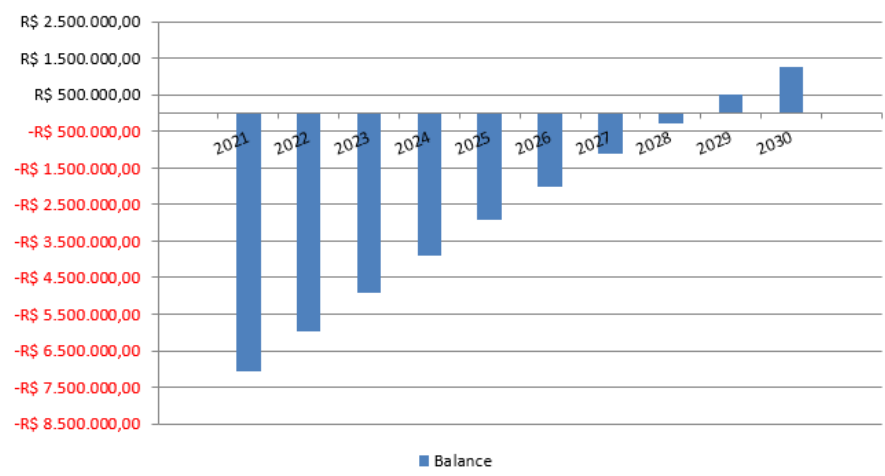

Figure 5 - Project return on investment.

Source: Own elaboration (2021).

Table 6 - Cost of the main components of the sizing system for the exploitation of biogas in landfills.

\begin{tabular}{|c|c|c|c|}
\hline \multicolumn{4}{|c|}{ Collection system } \\
\hline Component & Amount & $\operatorname{Cost}^{*}$ & Total \\
\hline Drains & 76 units & $\mathrm{R} \$ 2,199.04 /$ unit & $\mathrm{R} \$ 167,127.04$ \\
\hline Pipe & $3,750 \mathrm{~m}$ & $\mathrm{R} \$ 549.76 / \mathrm{m}$ & $\mathrm{R} \$ 2,061,600.00$ \\
\hline \multicolumn{4}{|c|}{ Treatment and purification system } \\
\hline Component & Amount & Cost & Total \\
\hline $\mathrm{H}_{2} \mathrm{O}$ coalescent filter & $29,048.310^{3} \mathrm{~m}^{3}$ & $\mathrm{R} \$ 0.02 / \mathrm{m}^{3}$ & $\mathrm{R} \$ 580,966.66$ \\
\hline $\mathrm{H}_{2} \mathrm{~S} /$ Siloxin & $29,048.310^{3} \mathrm{~m}^{3}$ & $\mathrm{R} \$ 0.02 / \mathrm{m}^{3}$ & $\mathrm{R} \$ 580,966.66$ \\
\hline $\mathrm{CO}_{2}$ & $29,048.310^{3} \mathrm{~m}^{3}$ & $\mathrm{R} \$ 0.02 / \mathrm{m}^{3}$ & $\mathrm{R} \$ 580,966.66$ \\
\hline \multicolumn{4}{|c|}{ Compression } \\
\hline Component & Amount & Cost & Total \\
\hline Low compression & $368.45 \mathrm{~m}^{3} / \mathrm{h}$ & $\mathrm{R} \$ 1,092.35 \mathrm{per} \mathrm{m}^{3} / \mathrm{h}$ & $\mathrm{R} \$ 402,472.69$ \\
\hline \multicolumn{4}{|c|}{ Burner } \\
\hline Component & Amount & Cost & Total \\
\hline Flare & 1 unit & $\mathrm{R} \$ 436,941.26 /$ unit & $\mathrm{R} \$ 436,941.26$ \\
\hline \multicolumn{4}{|c|}{ Electrical energy generation } \\
\hline Component & Amount & Cost & Total \\
\hline Motor-generator set & $1,200 \mathrm{~kW}$ & $\mathrm{R} \$ 2,184.71 / \mathrm{kW}$ & $\mathrm{R} \$ 2,621,652.00$ \\
\hline Grand total & & & $\mathrm{R} \$ 7,432,692.97$ \\
\hline
\end{tabular}

${ }^{\star}$ The values were corrected using the Central Bank of Brazil citizen calculator (BACEN, 2019a), from June 2016 (CETESB, 2006) to September 2019. Source: Own elaboration (2021). 
to those accounted for in this study, operational labor and security, management and administration, insurance, licenses, fees and professional services, for example. We suggest that in future studies all these and other factors that generate costs and revenues for the project should be analyzed.

Therefore, for the purposes proposed for this study, considering the costs and revenues evaluated and related to the implementation of the project in the studied landfill, the economic return will be positive and we suggest, then, that energy exploitation should be adopted on site. However, it is noteworthy that more in-depth and detailed studies, with regard to the project's costs and revenues, must be prepared in order to establish whether such additional values would make the project unfeasible.

\section{Conclusions}

The solid waste disposed each year in the landfill, according to the projection made, was able to provide enough biogas exploitation to generate electrical energy, in which, in the year with the highest peak of methane production, it can contribute to the consumption of approxi- mately 9,550 residences. The biogas utilization project, with a duration of 9 years and available power equal to $1,200 \mathrm{~kW} /$ year, proved to be viable according to the criteria used, even if not all the power available in the period has been used.

The importance of using biogas in landfills is highlighted as an environmentally adequate alternative, which conciliates both the final destination provided by Brazilian legislation for solid waste, and the use of gas generated by the mass of waste to generate a source of clean energy, bringing the possibility of diversifying the Brazilian energy matrix, and avoiding the emission of gases that aggravate the greenhouse effect.

The formation of consortia between small- and medium-sized municipalities is essential, as they collaborate with a better optimization of resources and minimization of environmental impacts. Studies like this one, which economically evaluates the implementation of biogas energy utilization projects in Brazilian landfills, are essential to demonstrate the economic and environmental benefits of adopting this practice, contributing, for example, to meeting the sustainable development goals and for the Brazilian nationally determined contribution.

\section{Contribution of authors:}

Souza, T.L.C.: Conceptualization, Methodology, Validation, Formal analysis, Investigation, Resources, Writing - original draft. Rocha, A.L.M.: Conceptualization, Methodology, Validation, Formal analysis, Investigation, Resources, Writing - original draft. Brianezi, D.: Conceptualization, Methodology, Validation, Formal analysis, Investigation, Resources, Writing - original draft.

\section{References}

Agência Nacional de Energia Elétrica - ANEEL. 2016. Resultados de leilões (Accessed October 25, 2019) at: https://www.aneel.gov.br/pt/resultados-de-leiloes.

Agência Nacional de Energia Elétrica - ANEEL. 2020. Sistema de Informações de Geração da ANEEL - SIGA (Accessed June 24, 2021) at: https://www.aneel. gov.br/siga.

Arcadis, T., 2010. Estudo sobre o potencial de geração de energia a partir de resíduos de saneamento (lixo, esgoto), visando incrementar o uso de biogás como fonte alternativa de energia renovável. Programa das Nações Unidas para o Desenvolvimento (PNUD) e Ministério do Meio Ambiente (MMA), São Paulo, 56 pp.

Associação Brasileira de Empresas de Limpeza Pública e Resíduos Especiais ABRELPE. 2013. Atlas brasileiro de emissões de GEE e potencial energético na destinação de resíduos sólidos. ABRELPE, São Paulo, 172 pp.

Associação Brasileira de Empresas de Limpeza Pública e Resíduos Especiais - ABRELPE. 2014. Panorama dos resíduos sólidos no Brasil. ABRELPE, São Paulo, 120 pp.

Associação Brasileira de Empresas de Limpeza Pública e Resíduos Especiais - ABRELPE. 2019. Panorama dos resíduos sólidos no Brasil. ABRELPE, São Paulo, 74 pp.

Banco Central do Brasil - BACEN. 2019a. Calculadora do cidadão (Accessed October 10, 2019) at: https://www3.bcb.gov.br/CALCIDADAO/publico/ exibirFormCorrecaoValores.do?method=exibirFormCorrecaoValores.
Banco Central do Brasil - BACEN. 2019b. Taxa Selic (Accessed November 8, 2019) at: https://www.bcb.gov.br/controleinflacao/taxaselic.

Barros, R.M. 2012. Tratado sobre resíduos sólidos: gestão, uso e sustentabilidade. Interciência, Rio de Janeiro; Acta, Minas Gerais, 374 pp.

Barros, R.M.; Tiago Filho, G.L.; Silva, T.R. 2014. The electric energy potential of landfill biogas in Brazil. Energy Policy, v. 65, 150-164. https://doi. org/10.1016/j.enpol.2013.10.028.

Bianek, J.; Schirmer, W.N.; Cabral, A.R.; Mayer, C.L.D.; Eurich, P.H.M.; Martins, E.H., 2018. Comparação entre metodologias USEPA e IPCC para estimativa teórica de produção de biogás em aterro municipal. Biofix Scientific Journal, v. 3, (1), 34-40. http://dx.doi.org/10.5380/biofix.v3i1.56038.

Bingemer, H.G.; Crutzen, P.J. 1987. The production of methane from solid wastes. Journal of Geophysical Research, v. 92, (D2), 2181-2187. https://doi. org/10.1029/JD092iD02p02181.

Brasil. 2010. Lei n ${ }^{\circ}$ 12.305, de 2 de agosto de 2010. Institui a Política Nacional de Resíduos Sólidos; altera a Lei no 9.605, de 12 de fevereiro de 1998; e dá outras providências. Diário Oficial da União.

Brasil. Ministério do Meio Ambiente. 2019. Aproveitamento energético do biogás de aterro sanitário (Accessed April 5, 2019) at: http://www.mma.gov.br/ cidades-sustentaveis/residuos-solidos/politica-nacional-de-residuos-solidos/ aproveitamento-energetico-do-biogas-de-aterro-sanitario. 
Casarotto Filho, N.; Kopittke, B.H. 1994. Análise de investimentos. Atlas, São Paulo, 447 pp.

Climatempo. 2019. Climatologia (Accessed October 22, 2019) at: https://www. climatempo.com.br.

Companhia Ambiental do Estado de São Paulo - CETESB. 2006. Manual do usuário do programa de computador Biogás: geração e uso energético aterros - versão 1.0. CETESB, Secretaria de Meio Ambiente, Ministério da Ciência e Tecnologia, São Paulo, 61 pp.

Costa, T.S. 2016. Estimativa de geração de biogás no aterro sanitário da bacia leiteira do estado de Alagoas. Master's dissertation, Centro de Ciências Agrárias, Universidade Federal de Alagoas, Rio Largo. Retrieved 2019-1011, from https://ceca.ufal.br/pt-br/pos-graduacao/energia-da-biomassa/ documentos/dissertacoes-ppgeb/dissertacoes-ppgeb.

Durão, J.V. 2017. Transição para o uso do biogás no brasil: análise baseada na perspectiva multinível. Doctoral Thesis, Instituto de Economia, Universidade Federal do Rio de Janeiro, Rio de Janeiro. Retrieved 2019-04-03, from https:// www.ie.ufrj.br/pos-graduacao-j/pos-graduacao-em-politicas-publicas/ dissertacoes-e-teses.html\#doutorado.

Empresa de Pesquisa Energética - EPE. 2018a. Anuário Estatístico de Energia Elétrica: ano base 2017. Ministério de Minas e Energia, Rio de Janeiro, 249 pp.

Empresa de Pesquisa Energética - EPE, 2018b. Balanço Energético Nacional 2018: ano base 2017. Empresa de Pesquisa Energética, Ministério de Minas e Energia, Rio de Janeiro, $294 \mathrm{pp}$.

Figueiredo, N.J.V. de. 2011. Utilização de biogás de aterro sanitário para geração de energia elétrica - estudo de caso. Master's dissertation, Energia, Universidade de São Paulo, São Paulo. doi:10.11606/D.86.2011.tde-11082011092549. Retrieved 2019-03-03, from www.teses.usp.br.

Freitas, C.O.; Makiya, I.K. 2012. Potencial energético a partir do biogás proveniente de aterros sanitários do Estado de São Paulo. In: Anais do XXXII Encontro Nacional de Engenharia de Produção. Desenvolvimento sustentável e responsabilidade social: as contribuições da engenharia de produção. Bento Gonçalves.

Gitman, L.J. 2010. Princípios da administração financeira. 12. ed. Pearson Prentice Hall, São Paulo, 801 pp.

Governos Locais pela Sustentabilidade - ICLEI. 2009. Manual do aproveitamento do biogás. Secretariado para a América Latina e Caribe, Escritório de Projetos no Brasil, São Paulo, v. 1, 80 pp.

Instituto Brasileiro de Geografia e Estatística - IBGE. 2000. Censo Demográfico: Tabela 200 - população residente, por sexo, situação e grupos de idade - amostra - características gerais da população (Accessed October 2, 2019) at: https://sidra.ibge.gov.br/tabela/200.

Instituto Brasileiro de Geografia e Estatística - IBGE. 2010. Censo Demográfico: Tabela 200 - população residente, por sexo, situação e grupos de idade - amostra - características gerais da população (Accessed October 2, 2019) at: https://sidra.ibge.gov.br/tabela/200.

Instituto Brasileiro de Geografia e Estatística - IBGE. 2018. Produto interno bruto dos municípios (Accessed April 15, 2021) at: https://www.ibge.gov.br/ estatisticas/economicas/contas-nacionais/9088-produto-interno-bruto-dosmunicipios.html? =\&t=o-que-e.

Intergovernmental Panel on Climate Change - IPCC. 1996. Revised 1996 IPCC Guidelines for National Greenhouse Gas Inventories. IPCC, United Kingdom (Accessed May 2, 2019) at: https://www.ipcc-nggip.iges.or.jp/public/ gl/invs6.html.
Intergovernmental Panel on Climate Change - IPCC. 2006. 2006 IPCC Guidelines for National Greenhouse Gas Inventories. IGES, Japan (Accessed May 20, 2019) at: https://www.ipcc-nggip.iges.or.jp/public/2006gl/spanish/vol5.html.

Intergovernmental Panel on Climate Change - IPCC. 2013. Fifth assessment report of the Intergovernmental Panel on Climate Change. Cambridge University Press, Cambridge, $1552 \mathrm{pp}$.

Johannessen, L.M. 1999. Guidance note on recuperation of landfill gas from municipal solid waste landfills. The World Bank, Washington, D.C., 34 pp.

Landim, A.L.P.F.; Azevedo, L.P. 2008. O aproveitamento energético do biogás em aterros sanitários: unindo o útil ao sustentável. BNDES Setorial, (27), 59-100 (Accessed Apr 6, 2019) at: http://web.bndes.gov.br/bib/jspui/ handle/1408/2433.

Motta, R.R.; Calôba, G.M. 2002. Análise de investimentos: tomada de decisão em projetos industriais. Atlas, São Paulo, 392 pp.

Nascimento, M.C.B.; Freire, E.P.; Dantas, F.A.S.; Giansante, M.B. 2019. Estado da arte dos aterros de resíduos sólidos urbanos que aproveitam o biogás para geração de energia elétrica e biometano no Brasil. Engenharia Sanitária e Ambiental, v. 24, (1), 143-155. https://doi.org/10.1590/S1413-41522019171125.

Programa das Nações Unidas para o Desenvolvimento - PNUD. 2010. Ranking IDHM Municípios 2010 (Accessed April 15, 2021) at: https://www.br.undp.org/ content/brazil/pt/home/idh0/rankings/idhm-municipios-2010.html.

Qasim, S.R., 1985. Wastewater treatment plants: planning, design and operation. Holt, Rinehart and Winston, New York, 608 pp.

Samanez, C.P., 2002. Matemática financeira: aplicações à análise de investimentos. 3. ed. Prentice Hall, São Paulo, 380 pp.

Santos, I.F.S. 2015. Proposta de um método escalonado para a motorização do aproveitamento do biogás gerado por aterros sanitários para fins de geração de energia elétrica. Master's dissertation, Engenharia de Energia, Universidade Federal de Itajubá, Itajubá. Retrieved 2019-10-12, from https://repositorio. unifei.edu.br/jspui/handle/123456789/162.

Silva, T.N.; Freitas, F.S.N.; Candiani, G. 2013. Avaliação das emissões superficiais do gás de aterros sanitários de grande porte. Engenharia Sanitária e Ambiental, v. 18, (2), 95-104. https://doi.org/10.1590/S1413-41522013000200001.

United States Environment Protection Agency - USEPA. 2008. Final assessment report: landfill biogas recovery and utilization at the solid waste treatment center BR-040 Belo Horizonte, Brazil. Eastern Research Group, Inc. and MGM International Group, LLC, 35 pp.

United States Environment Protection Agency - USEPA, 2021. Landfill Methane Outreach Program (LMOP): basic information about landfill gas (Accessed April 16, 2021) at: https://www.epa.gov/lmop/basic-informationabout-landfill-gas.

Van Elk, A.G.H.P. 2007. Redução de emissões na disposição final. Ibam, Rio de Janeiro, $44 \mathrm{pp}$.

Vieira, G.E.G.; Campos, C.E.A.; Teixeira, L.F.; Colen, A.G.N. 2015. Produção de biogás em áreas de aterros sanitários: uma revisão. Revista Liberato, v. 16, (26), 193-204. http://doi.org/10.31514/rliberato.2015v16n26.p193.

World Bank. 2004. Energy Sector Management Assistance Programme. Handbook for the preparation of landfill gas to energy projects in Latin America and the Caribbean. World Bank, Conestoga-Rovers \& Associates, $236 \mathrm{pp}$. 